3. Zahaikevych, M. (1973). Levko Kolodub. Creative portraits of Ukrainian composers. Kyiv: Muzychna Ukraina.

4. Makarenko, L. (2015). Folk principles of Lev Kolodub's orchestral creativity. Vinnytsia: Nova Knyha.

5. Mukha, A. (1963). Ukrainian Carpathian rhapsody by L. Kolodub. Kyiv: Mystetstvo.

(С) Макаренко Л. П., 2018

УДК: 784.9(477-25)"195"

Небога Олеся Григорівна

аспірантка,

Київський національний університет

культури та мистецтвв,

Київ, Украӥна

lesigor@rambler.ru

\title{
КИЇВСЬКА ШКОЛА СОЛЬНОГО СПІВУ СЕРЕДИНИ ХХ СТОЛІТТЯ ЯК ФЕНОМЕН ЄВРОПЕЙСЬКОГО ВОКАЛЬНОГО ВИКОНАВСТВА
}

Мета дослідження. Сформувати системне розуміння явища київської вокальної школи через аналіз різних іï напрямків, які сформувалися в середині та другій пол. ХХ ст. і реалізувалися у виконавській та педагогічній практиці викладачів Національної музичної академії України ім. П. І. Чайковського (Київська консерваторія). Зокрема йдеться про школи О. Муравйової, М. Донець-Тесейр, К. Брун, І. Паторжинського та одеських педагогів, що працювали в консерваторії - Є. Чавдар, Б. Руденко та З. Христич. Метою дослідження $\epsilon$ формування системного розуміння явища київської вокальної школи та довести іiі виключно важливу роль серед ін. європейських шкіл. Методи дослідження полягають у використанні феноменологічного методу (як пошук рис, що допомогли б назвати явище феноменом) та історичного методу. Ключовим моментом проблематики даної статті є розуміння Київської школи сольного співу як феномену. Наукова новизна полягає в тому, що київська вокальна школа системно досліджується як феномен у контексті ін. шкіл. Окрім цього, вперше аналізується низка маловідомих напрямків, які, свого часу були оригінальними явищами в процесі іiі розвитку. Висновки: Київська школа сольного співу дійсно є школою, за своєю сутністю, а іï національне коріння та синтез характерних рис західноєвропейської (зокрема італійської) та російської шкіл визначають іï як справжній феномен європейського та світового вокального виконавства. При цьому - 3 великою часткою самобутності, різнобарв'ям педагогічних та наукових підходів, що робить ії знаковим явищем на теренах світового вокального виконавства. 
Ключові слова: вокал, школа, методика, консерваторія, феномен.

Небога Олеся Григорьевна, аспирантка, Киевский нацчональный университет культуры и искусств, Киев, Украина

Киевская школа сольного пения в середине XX ст. как феномен европейского вокального исполнительства

Целью исследования была попытка сформировать системное понимание явления киевской вокальной школы через анализ различных её направлений, которые сформировались в середине и второй половине XX века, и реализовались в исполнительской и педагогической практике преподавателей Национальной музыкальной академии Украины им. П. И. Чайковского (Киевская консерватория). В частности речь идет о школах Е. Муравьевой, М. Донец-Тесейр, К. Брун, И. Паторжинского и одесских педагогов, преподававших в консерватории в то же время - Е. Чавдар, Б. Руденко и 3. Христич. Методы исследования состоят в использовании феноменологического метода (как поиск характеристик, которые помогли бы назвать явление феноменом) и исторического метода. Ключевым моментом проблематики данной статьи является понимание Киевской школы сольного пения как феномена. Научная новизна заключается в том, что киевская вокальная школа системно исследуется как феномен в контексте других школ. Кроме этого, впервые анализируется ряд малоизвестных направлений, которые в свое время были оригинальным явлением в процессе ее развития. Выводы: Киевская школа сольного пения действительно является школой, по своей сути, a eе национальные корни и синтез характерных черт западноевропейской (в частности итальянской) и российской школ определяют ее как настоящий феномен европейского и мирового вокального исполнительства. При этом с большой долей самобытности, разнообразием педагогических и научных подходов, что делает ее знаковым явлением на территории мирового вокального исполнительства.

Ключевые слова: вокал, школа, методика, консерватория, феномен.

Neboha Olesia, postgraduate, Kyiv National University of Culture and Arts, Kyiv, Ukraine

Kyiv school of solo singing in the middle of the $20^{\text {th }}$ century as a phemonenon of European vocal performance

The purpose of the article is to create a systemic understanding of the phenomenon of Kyiv vocal school through the analysis of its various directions, which were formed in the middle and late $20^{\text {th }}$ century and were realized in the performing and pedagogical practice of the teachers of Petro Tchaikovsky National Music Academy of Ukraine (Kyiv Conservatory). In particular, the article deals with the schools of Olena Muravyova, Mariia Donets-Teseir, Clara Brun, Ivan Patorzhinsky and Odessa teachers who worked at the Conservatory at the same time Yelizaveta Chavdar, Bella Rudenko and Zoya Khrystych. The purpose of the study is to form a systemic understanding of the phenomenon of Kyiv vocal school and to 
prove its exceptionally important role among other European schools. The research methodology consisted in the application of the phenomenological method (search for the features which would help to call the subject of research a phenomenon) and the method of historicism. The key point of the problematics of this article is understanding Kyiv school of solo singing as a phenomenon. The scientific novelty of the work lies in the fact that Kyiv vocal school was systemically studied as a phenomenon in the context of other schools. In addition, a number of little-known directions were analyzed for the first time, which were once original phenomena in the process of its development. Conclusions. Kyiv school of solo singing is indeed a school of its own, and its national roots and the synthesis of the characteristic features of Western European (Italian, in particular) and Russian schools define it as a true phenomenon of European and world vocal performance. At the same time, it possesses a large part of identity, colorful pedagogical and scientific approaches, which makes it a significant phenomenon in the world of vocal singing.

Key words: vocal, school, methodology, conservatory, phenomenon.

Вступ. Актуальність поданої статті полягає у відсутності системного осмислення повної картини феномену під назвою «київська школа сольного співу». Поміж тим київська школа сольного співу, класичний вигляд якої сформувався в середині та другій пол. минулого століття, сьогодні займає важливе місце, посеред багатьох інших осередків світової традиції академічного вокалу. Як відомо, українці віддавна славляться своїми співочими голосами, тому процес формування повноцінної школи сольного співу на теренах нашої країни - не виглядає чимось дивним. У своєму класичному вигляді українські школи сольного співу сформувалися на початку та в середині XX ст., у період творчої діяльності видатних корифеїв та викладачів О. Мишуги, С. Крушельницької, Д. Свтушенка, Б. Гмирі, М. Донець-Тессейр, М Кондратюка, Є. Мірошніченко, I. Паторжинського, А. Кочерги. Сьогодні спадкоємці видатної плеяди зірок, які передають власні знання учням та виховують співаків, які користуються популярністю в Україні та за кордоном.

Центральним осередком підготовки нових кадрів у галузі сольного співу $\epsilon$, як відомо, Національна музична академія України ім. Петра Ілліча Чайковського. Саме в іiі стінах сформувалося кілька вокально-методичних концепцій, які сьогодні утворюють київську вокальну школу.

В одній $з$ них сповідується симбіоз співака із, власне, героєм. Інакше кажучи, соліст має повністю вжитися в образ ліричного героя чи то романсу, чи то оперної постановки, і вже як наслідок, обирати відповідні засоби для його втілення. Зокрема, такий підхід мав би прищепити власним учням видатний педагог Дометій Гурійович Свтушенко - учень славнозвісної Олени Муравйової.

3 іншого боку, існує концепція анатомо-фізіологічної побудови вокального апарату як основи для розвитку голосових можливостей. Її основи були закладені ще в діяльності Олександра Мишуги (тобто, до фактичного відкриття консерваторії), а згодом - розвинуті в діяльності Марії Едуардівни Донець-Тесейр, Михайла Микиши та ін. їхніх сучасників та учнів. Окрім 
перерахованих, існують декілька менш відомих напрямків, які, ще не дістали належного наукового осмислення.

Тож об’єктом пропонованого дослідження є київська школа сольного академічного співу.

Предмет дослідження: педагогічні напрямки київської вокальної школи та їхня феноменологічна сутність у контексті європейської традиції вокального виконавства.

Методологічна основа статті побудована на використанні методу феноменології як основного, та історизму - як додаткового. Як наслідок, ключовим моментом проблематики даної статті $є$ розуміння Київської школи сольного співу як феномену. У філософському сенсі цього поняття, феноменом можна називати те, що ми пізнаємо за рахунок власного досвіду, виокремлюючи з-поміж іншого. Насамперед, для успішного результату важливим $\epsilon$ виокремити певні характеристики, які, власне, i дадуть змогу виокремити саме явище та визначити його як феномен. Інакше кажучи, феномен київської вокальної школи має власний фенотип (під ним розуміється сукупність характеристик, що визначають явище на певній стадії розвитку).

Дмитро Аселунд надає наступне визначення явищу вокально-педагогічна школа: «це конкретна, цілеспрямована, організована система підготовки нових поколінь співаків та педагогів для конкретної діяльності, що історично змінюється» [33, с. 4]. Б. Гнидь у монографії «Історія вокального мистецтва», вважає, що «таке поняття можна вживати як визначення української, італійської, французької, німецької, російської, болонської та ін. вокальних шкіл. Вокальна школа історично змінна, соціальна та національна. Процес історичної змінності вокальних шкіл завжди нерозривно пов'язаний 3 історичним розвитком музики, 3 конкретними вимогами виконавської практики. <...> Соціальні умови визначають ідейну та естетичну направленість вокального мистецтва, а також впливають на характер вокальних шкіл. <..> Національний характер вокальних шкіл обумовлений складом життя кожного народу: його поезією, законами фонетики, мови, народними традиціями в музиці, мистецтвом народних співаків» [Ошибка! Источник ссылки не найден.5, с. 3].

Новизна й оригінальність статті полягає в тому, що вперше київська вокальна школа системно досліджується як феномен у контексті ін. шкіл. Окрім цього, вперше аналізується низка маловідомих напрямків, які, свого часу були досить оригінальними явищами в процесі іiі розвитку.

Мета даної статті полягає в формуванні системного розуміння явища київської вокальної школи та довести пї виключно важливу роль серед ін. європейських шкіл.

Виклад основного матеріалу статті. Становлення та розвиток київської вокальної школи виявився одним із аспектів загального пожвавлення культурного та освітнього процесу на теренах України на поч. XX ст. Відомо, що саме в цей час відкриваються професійні музичні навчальні заклади різного рівня (від шкіл - до консерваторій), причому - не лише в Києві. Саме в цей час, 
у Києві працює такий видатний вокальний педагог як Олександр Мишуга, а 31907 p. - Олена Муравйова. Обидва педагоги випустили досить велику плеяду провідних виконавців, відомих в Україні й за їі межами та сформували цілі вокально-педагогічні династії, представники яких працюють у Національній музичній академії та ін. навчальних закладах - до сьогодення. Приміром, вихованцями Олени Олександрівни Муравйової були такі постаті як 3. Гайдай, Д. Свтушенко, Н. Захарченко, Р. Разумова, І. Колесникова, І. Вілінська та ін.

Вихованцями Олександра Мишуги були такі славетні співаки як Марія Едуардівна Донець-Тесейр та Михайло Микиша. Надалі Марія Едуардівна сформувала власну вокально-педагогічну школу, положення якої засновані на системі О. Мишуги та італійській школі (як відомо, співачка навчалася в Міланській консерваторії в професора В. Ванцо). Ї̈ї представниками були такі постаті як I. Масленикова, М. Звєздіна, Т. Петрова, Є. Мирошииченко, Н. Куделя, Р. Колесник, М. Міщенко, А. Савченко, М. Малій. Р. Науменко, М. Сгоричева, Н. Макарова, Р. Зінич, М. Лепихова, Г. Блажко.

Окрім цих двох напрямків були й інші, менш відомі. Приміром, можна виділити педагогічні концепції К. Брун та І. Паторжинського. Важливий внесок у становлення київської вокальної школи зробили викладачі та співаки з Одеси на чолі з видатною Єлизаветою Іванівною Чавдар. Тож охарактеризуємо особливості кожного з перелічених напрямків.

Як можна зрозуміти 3 попереднього абзацу, найбільш розгалуженим методичним напрямком була школа однієї з найбільших українських вокальних педагогів Олени Олександрівни Муравйової. Вона отримала свій подальший розвиток у діяльності учнів Олени Олександрівни, зокрема - у професора Дометія Гурійовича Євтушенка, Зої Михайлівни Гайдай та Елли Олександрівни Акритової.

На наш погляд, у всіх вокально-методичних школах існує низка універсальних положень. Однак кожен напрямок відрізняє особлива увага чи пріоритет до окремих компонентів виконавства, що призводить до появи іманентних характеристик, властивих тільки даному напрямку. Так, основними рисами школи професора О. Муравйової та іiі учнів $є$ дбайливе, уважне ставлення до тембру голосу учня, виявлення та вдосконалення кращих його індивідуальних особливостей на основі легкого головного звучання. Велика увага приділяється й ритмічній точності виконання (без зловживань агогічними люфтами) та емоційній щирості, що проявляється у вмінні бути актором та проживати сценічне життя героя музичного твору. Тому Олена Олександрівна з таким надзвичайним педагогічним талантом варіювала і вправи, i твори, i весь підхід до учнів при вихованні їхніх голосів.

Показовим може бути висловлювання про виступ однієї з найбільш обдарованих учениць співачки - Елли Олексіївни Акритової. Так, у журналі «Радянська музика» А. Григор'єва пише наступне: «Її голос звучав легко, вільно, природно. Співачка зі справжнім артистизмом передала авторський задум, зафіксувавши елегійний драматизм, або печальний роздум, в романсі «Якби мені черевики»/M. Скорика - O. H/, тонко, майже імпресіоністське 
відчуття природи у другому («За сонцем хмаронька пливе») /також М. Скорика - О. Н/» [66, с. 39].

Другим методичним спрямуванням, що у значній мірі сприяв зростанню слави й авторитету київської школи, є напрям професора М. Е. Донець-Тесейр. У його основі лежить симбіоз манери російської та італійської вокальної шкіл, а також - народного співу ліричних пісень. Використавши кращі досягнення цих шкіл, вона створила свій метод виховання блискучою, віртуозної техніки у легких сопрано, на основі дуже сконцентрованого струменя видиху в умовах дуже чіткої фонетики при вимові слів. Цей метод є одним з провідних при підготовці лірико-колоратурних сопрано.

Вийшла за межі виховання тільки легких жіночих голосів i Ірина Степанівна Колодуб. 31966 р. вона була асистентом у М. Е. Донець-Тесейр та їі учениці -професора М. Сгоричевої. Будучи дуже ерудованою людиною, маючи вищу технічну освіту, вільно володіючи фортепіано, Ірина Степанівна провела велику роботу з підготовки курсу методики викладання сольного співу.

Інший, менш відомий напрямок київської школи сольного співу належить Кларі Ісаківни Брун. Ї̈̈ також можна вважати прикладом засвоєння італійської вокальної школи та асиміляції на грунті російської музичної культури. Клара Ісаківна закінчила Віденську консерваторію, потім удосконалювалася в Італії у професора А. Россі. Це школа високої співочої позиції з хорошою опорою дихання, яскравого резонування та злагодженості голосних, i, головне, високого рівня самоконтролю при співі.

Школа Олександра Олександровича Гродзинського своїм корінням сягає періоду формування в Києві професійної вокальної педагогіки. Олександру Олександровичу довелося вчитися в Київській консерваторії в професора В. О. Цвєткова. Олександр Олександрович багато років був одним 3 кращих в Київській консерваторії вихователем баритонів, прищеплюючи їм хороший академічний музичний смак, домагаючись округлого, яскравого резонансного звучання на хорошій дихальній опорі, і точного прочитання музичного тексту. Про особливості його методики дуже красномовно написано у статті В. Антонюк: «Оте хворобливо-точне відчуття інтонації правди, якої вимагав професор О. Гродзинський від своїх вихованців, незалежно від того, якою мовою i в якому стилі чи жанрі вокальної музики вони творили, стало прикметною ознакою творчості представника його школи <...>М. Кондратюка. Спів його в будь-якій просторово-часовій іпостасі свого баритонового звуковияву завжди справляє враження створюваної в присутності слухачів талановитої імпровізації - якості, притаманної справдешнім майстрам» [2Ошибка! Источник ссылки не найден., с. 4].

Нині не дуже відомим $є$ факт, що видатний український співак Іван Паторжинський, свого часу також мав власну педагогічну систему, яка, між іншим, була досить оригінальною. Можливо, це пов'язане ще й з тим, що його педагогічний мето сформувався за межами кафедри сольного співу Київської консерваторії та є прикладом синтезу різних вокально-методичних напрямків на Україні. Сам Іван Сергійович називав власний метод «комплексним», 
передбачаючи паралельний (тобто, без пріоритетів, як це можна було спостерігати в інших педагогів) розвиток акторської майстерності, голосової техніки та осмисленого проспівування словесного тексту, незалежно від жанрово-стильових координат твору. Цей метод дозволив професору I. Паторжинському виховати плеяду відмінних співаків акторів, в основному басів і баритонів.

У середині 60-х рр. до Київської консерваторії прийшла група педагогіввихованців Одеської консерваторії - Слизавета Чавдар, народна артистка Белла Руденко та Зоя Христич.

Слизавета Іванівна Чавдар з відзнакою закінчила Одеську консерваторію в 1948 р. Блискуче виступила на показі випускників консерваторій України та в тому ж році була запрошена до Київського театру опери і балету. Особливо теплий за тембром голос, блискуче володіння вокальною технікою, акторське обдарування і вміння з неослабною наполегливістю безперервно працювати над вдосконаленням своєї майстерності, дозволили Єлизаветі Іванівні в короткий час завоювати становище одного з провідних лірико-колоратурних сопрано.

Зоя Петрівна Христич і Белла Андріївна Руденко є вихованками одного 3 провідних українських вокальних педагогів Ольги Миколаївни Благовидової, яка протягом багатьох років очолювала кафедру сольного співу Одеської консерваторії.

Зоя Петрівна закінчила консерваторію в 1956 р. і була запрошена до Київського оперного театру. Вона володіла ліричним сопрано надзвичайно красивого тембру, що в поєднанні з відмінною вокальною школою дало ій можливість у короткий термін зайняти провідне становище в театрі та завоювати звання лауреата на чотирьох міжнародних конкурсах вокалістів.

У педагогів цієї генерації техніка ніколи не була самоціллю. Головним, перш за все, були сценічні образи та емоції, які втілювалися в них. Але при цьому, усі три представниці одеської вокальної школи в межах київської були надзвичайно вимогливими щодо прозорості й чистоти тембру, виключаючи нечисті призвуки при виконанні.

Наукова новизна полягає в тому, що київська вокальна школа системно досліджується як феномен у контексті ін. шкіл. Окрім цього, вперше аналізується низка маловідомих напрямків, які, свого часу були оригінальними явищами в процесі їі розвитку.

Висновки Тож нами було проаналізовано низку напрямків, які сформували класичний вигляд київської вокальної школи в середині минулого століття. Кожен 3 них містить як певні унікальні властивості, так й інтерпретування загальних технічних принципів академічного сольного співу. Виходячи $з$ того, як поняття «вокально-методична школа» визначена в роботі Б. Гнидя, можна зробити наступні висновки.

По-перше, кожен із розглянутих напрямків $є$ результатом розвитку та акумулювання засад різних шкіл академічного співу - від італійського bel canto, до російської школи 3 тяжінням до емоційної щирості та осмисленості виконання. Тобто, поява та розвиток київської школи сольного співу виявилися 
природнім результатом музично-історичного розвитку та прикладом наслідування традицій шкіл старших поколінь.

По-друге, для київської вокальної школи є властива спроба поєднати засади інтонування українських народних пісень 3 характерними, для академічного вокалу, засадами й виконавськими принципами. Незважаючи на дещо різні педагогічні підходи та методики, кожен з розглянутих напрямків демонструє інтерес до, так би мовити, нац̧інальної української інтонації̈. Приклади такого ставлення спостерігаються в системах М. Е. Донець-Тесейр, Д.Г. Свтушенка (фактично О. Муравйової), М. І. Кондратюка, I. С. Паторжинського та їхніх учнів.

По-третє, сам факт поєднання італійської, російської та української вокальних шкіл свідчить про унікальний досвід київської вокальної школи. Педагоги Київської консерваторії були одними з перших в Україні, хто не лише практикували подібні симбіотичні підходи у виконавській практиці, а ще й надали цьому науково-методичне обгрунтування у великій кількості наукових праць, доповідей та статей. Тож можемо зауважити і про унікальні особливості, які притаманні саме київській школі сольного співу.

Усе вищенаведене переконливо доводить, що цю школу можна вважати феноменом (з огляду на наведені на початку статті дефініціі). Київська школа сольного співу дійсно є школою, за своєю сутністю, а їі національне коріння та синтез характерних рис західноєвропейської (зокрема італійської) та російської шкіл визначають иï як справжній феномен європейського та світового вокального виконавства. При цьому - 3 великою часткою самобутності, різнобарв'ям педагогічних та наукових підходів, що робить ії знаковим явищем на теренах світового вокального виконавства.

\section{Список використаних джерел}

1. Акритова Е. О. Професор О. О. Муравйова / Е. О. Акритова // Виконавські школи вищих учбових заходів України: зб. наук. пр. - Київ, 1990. - С. 79-85.

2. Антонюк В. Г. Етномузикологічні тенденції української вокальної школи (з творчо-педагогічного досвіду професора Національної Музичної Академії України ім. П. І. Чайковського М. К. Кондратюка) / В. Г. Антонюк // Вісн. Держ. акад. керівних кадрів культури і мистецтв. - Київ, 1999. - № 2. - С. 119-122

3. Аселунд Д. Развитие певца и его голоса / Д. Аселунд. - СанктПетербург : Лань, Планета музыки, 2016. - 180 с.

4. Берегова О. Музично-виконавські школи України: етапи становлення у XX столітті/ О. Берегова // Наук. вісн. нац. муз. акад. України ім. П. І. Чайковського. - Київ, 2008. - Вип. 67. - С. 131-150.

5. Гнидь Б. П. Історія вокального мистецтва / Б. Гнидь. - Київ : Нац. муз. акад. України ім. П. І. Чайковського, 1997. - 319 с.

6. Григорьева А. (об Э. Акритовой) / А. Григорьева // Советская музыка. 1975. - №3. - C. 37

\footnotetext{
${ }^{3}$ «Це визначення належить автору статті і $є$ не терміном, а епітетом». - О. Н
} 
7. Людкевич С. Олександр Мишуга як артист і вчитель співу/ С. Людкевич// Дослідження, статті, рецензії, виступи. - Львів : Вид-во М. Коць «Дивосвіт», 1999. - Т.1. - С. 430-438.

8. Михайлова Т. Вокально-методические школы, сложившиеся в киевской консерватории: рукопис / Т. Михайлова. - Киев : Нац. муз. акад. Украини им. П. И. Чайковского. - С. 1-18

\section{Reference}

1. Akrytova, E. (1990). Professor O. Muravyova. Vykonavski shkoly vyshchykh uchbovykh zakhodiv Ukrainy [Schools of musical performance at Ukrainian universities], pp. $79-85$.

2. Antoniuk, V. (1998)/ Ethnic and musicological features of Ukrainian vocal school (from the artistic and pedagogical experiences of M. Kondratiuk). Visnyk Derzhavnoi Akademii Kerivnykh Kadriv Kultury ta mystetstv [Bulletin of National Academy of Government Managerial Staff of Culture and Arts], no.2, pp.119-122.

3. Aselund, D. (2016). Development of the singer and his voice. Saint Petersburg: Lan, Planeta muzyki, $180 \mathrm{p}$.

4. Berehova, O. (2008). Ukrainian schools musical performance: stages of formation in the $20^{\text {th }}$ century. Naukovyi visnyk Natsionalnoi muzychnoi akademii imeni P. Chaikovskoho [Bulletin of Petro Tchaikovsky National Music Academy of Ukraine], vol. 63, pp. $131-150$.

5. Hnyd, B. (1997). The history of vocal art. Kyiv: Petro Tchaikovsky National Music Academy of Ukraine.

6. Grigor'eva, A. and E. Akrytova (1975). Sovetskaya muzyka [The Soviet music], 3, p. 37

7. Liudkevych, S. (1999). Oleksandr Mishuha as a performer and singing teacher. Researches, articles, reviews. Vol. 1. Lviv: Dyvosvit, pp. 430 - 438.

8. Mykhailova, T. (1975). Vocal schools founded in Kyiv Conservatory. Kyiv: Petro Tchaikovsky National Music Academy of Ukraine. pp. 1-18.

(C) Небога О. Г., 2018 